Al-Bidayah : jurnal pendidikan dasar Islam

Volume 12, Number 2, December 2020

ISSN: 2549-3388 (online)

Available online at https://jurnal.albidayah.id

Submitted: October 7, 2020, Accepted: December 28, 2020

\title{
THE INFLUENCE OF INTERACTIONAL TEACHING STYLE ON THE INDEPENDENCE CHARACTERS OF ELEMENTARY SCHOOL STUDENTS
}

\section{Diah Fitrotul Auliana ${ }^{1}$, Arief Rahman Hakim², Dyah Triwayuningtyas ${ }^{3}$, Yulianti', Mohm Faiz Mohd Yaakob ${ }^{5}$, Diana Wulandari ${ }^{6}$}

\author{
Universitas PGRI Kanjuruhan Malang, Indonesia ${ }^{1,2,3,4}$, Universiti Utara Malaysia, \\ Malaysia $^{5,6}$ \\ E-mail: diahfitrotul07@gmail.com ${ }^{1}$, ariefrahman@unikama.ac.id ${ }^{2}$, \\ dyahtriwahyu@unikama.ac.id ${ }^{3}$, yulianti@unikama.ac.id ${ }^{4}$, \\ mohd.faiz@uum.edu.my ${ }^{5}$,wulandaridiana87@gmail.com ${ }^{6}$
}

DOI: 10.14421/al-bidayah.v12i2.576

\begin{abstract}
This study is motivated by teachers' existence in elementary schools (ES), especially in grades IV, V, and VI, because there are still many who use traditional teaching styles. This makes it difficult for students to understand the learning material, and students are less independent in the learning process. A significant influence between teacher teaching styles that are interactional on the independent character of elementary school students. This research uses quantitative methods with data analysis; validity test, reliability test, normality test, simple linear regression test. In contrast, the sample in this study was selected randomly, namely students in grades IV, V, and VI at ES at SDN Ketapanrame 1 Trawas. The data analysis results showed a significant influence between the interactional teaching style of the teacher on the independent character of elementary school students as evidenced by the t-test results of 5.386 with a significant level of .000 . The interactional teaching style affected the independent character of students.
\end{abstract}

Keywords: teacher teaching style; independent character; elementary school students

\section{INTRODUCTION}

Teachers have an important role in determining student learning success. ${ }^{1}$ This success is in addition to the aspects of knowledge and skills, but the attitude or character of students is the main orientation of success in the learning process. Teachers are the main holders of learning, especially in shaping the character of their students. ${ }^{2}$

1 Ika Maryani and Sri Tutur Martaningsih, "Primary School Teachers' Perception About Curriculum 2013 Assessment System," Scholaria: Jurnal Pendidikan Dan Kebudayaan 7, no. 2 (2017): 153-64, https://doi.org/10.24246/j.scholaria.2017.v7.i2.p153-164.; Rusman Rusman, "Implementasi Kurikulum 2013 Di Sekolah Dasar Studi Tentang Best Practice Yang Dilakukan Guru Sekolah Dasar Dalam Perencanaan, Pelaksanaan, Dan Penilaian Kurikulum 2013," Al-Bidayah: Jurnal Pendidikan Dasar Islam 10, no. 2 (2018): 135-50, https://doi.org/10.14421/al-bidayah.v10i2.166.; HM Zainuddin, "Implementasi Kurikulum 2013 Dalam Membentuk Karakter Anak Bangsa," Universum: Jurnal KeIslaman Dan Kebudayaan 9, no. 1 (2015), https://doi.org/10.30762/universum.v9i1.80.

${ }^{2}$ Cornelius Brandmiller, Hanna Dumont, and Michael Becker, "Teacher Perceptions Of Learning Motivation And Classroom Behavior: The Role Of Student Characteristics," Contemporary Educational Psychology 63 (2020): 101893, https://doi.org/10.1016/j.cedpsych.2020.101893. 
The formation of the character of students by teachers is very necessary for every school. ${ }^{3}$ The government formulates five main characters: religious, nationalist, independent, cooperation, and integrity. ${ }^{4}$ In the 2013 curriculum, students' independent character is also very necessary because the independent character is included in the values of Character Education Strengthening (CES). ${ }^{5}$ Independent means not depending on other people or friends and using energy, thoughts, time to realize their hopes, dreams, and aspirations. ${ }^{6}$

Teachers, as an element of student learning success, need to understand the characteristics of elementary school students, establish interactions with students for their academic achievements ${ }^{7}$ and pay attention to the principles in implementing the 2013 curriculum, one of which is to provide opportunities for students to learn independently by utilizing technology information and communication. Understanding this makes it possible for a shift in teaching styles to occur and create students to have character. $^{8}$

The teaching style of educators is a technique, tactic, method, or method used during the teaching and learning process. ${ }^{9}$ Strengthening character education is very important in a learning process so that students get what a teacher wants. This is where a teacher's teaching style is needed. Besides, the teacher's teaching style is an educator's habit of using methods or methods in conveying teaching content. The teacher's teaching style is a form of the teacher's behavior in conveying the content of learning,

${ }^{3}$ Mangun Budiyanto and Imam Machali, "Pembentukan Karakter Mandiri Melalui Pendidikan Agriculture Di Pondok Pesantren Islamic Studies Center Aswaja Lintang Songo Piyungan Bantul Yogyakarta," Jurnal Pendidikan Karakter, no. 2 (2014), https://doi.org/10.21831/jpk.v0i2.2784.

${ }^{4}$ Ministry of Education and Culture, Kajian Dan Pedoman Penguatan Pendidikan Karakter (PPK), (Jakarta: MoEC, 2016).

5 Rahmi Fahmy et al., "Measuring Student Perceptions To Personal Characters Building In Education: An Indonesian Case In Implementing New Curriculum In High School," Procedia-Social and Behavioral Sciences 211 (2015): 851-58, https://doi.org/10.1016/j.sbspro.2015.11.112.

${ }^{6}$ Hendro Widodo, "Penguatan Pendidikan Karakter Di SD Muhammadiyah Macanan Sleman Yogyakarta," Lentera Pendidikan: Jurnal Ilmu Tarbiyah Dan Keguruan 22, no. 1 (2019): 40-51, https://doi.org/10.24252/lp.2019v22n1i4.

${ }^{7}$ Christine L Bae, Morgan Les DeBusk-Lane, and Ashlee M Lester, "Engagement Profiles Of Elementary Students In Urban Schools," Contemporary Educational Psychology 62 (2020): 101880, https://doi.org/10.1016/j.cedpsych.2020.101880.

${ }^{8}$ Ilin Nurhamidah, "Problematika Kompetensi Pedagogi Guru Terhadap Karakteristik Peserta Didik," Jurnal Teori Dan Praksis Pembelajaran IPS, 2018, 27-38, http://dx.doi.org/10.17977/um022v3i12018p027.

${ }^{9}$ Yalçın Dilekli and Erdoğan Tezci, “The Relationship Among Teachers' Classroom Practices For Teaching Thinking Skills, Teachers' Self-Efficacy Towards Teaching Thinking Skills And Teachers' Teaching Styles," Thinking Skills and Creativity 21 (2016): 144-51, https://doi.org/10.1016/j.tsc.2016.06.001. 
Diah Fitrotul Auliana, Arief Rahman Hakim, Dyah Triwayuningtyas, Yulianti, Mohm Faiz Mohd Yaakob, Diana Wulandari

guiding, and developing students' abilities to carry out the teaching and learning process using classical, technological, personalization, and interactional teaching styles. ${ }^{10}$

Teachers in the learning process have several teaching styles, including a) Classical teaching styles; a series of learning procedures were simultaneously and togetherness, learning activities are carried out by all students together in one class. ${ }^{11} \mathrm{~b}$ ). Technological teaching style; the teaching style of teachers who deliver learning material is programmed in the media. ${ }^{12}$ Technological teaching styles are very dependent on the use of media to convey learning materials so that teachers are no longer viewed as a central point in learning. ${ }^{13} \mathrm{c}$ ). Personalized teaching styles are based on the preferences, skills, and psychological growth systems of students d). In this interactional teacher's teaching style, the position of an educator and students is seen in this style. They are equally influential. ${ }^{14}$ This teaching style, usually in the context of learning, focuses on events related to society's social and cultural aspects, especially on current characteristics. ${ }^{15}$ Besides, the international teaching style also adjusts at the stage of student development to feel comfortable and more independent in the learning process. ${ }^{16}$

Independent character is an attempt to regulate and control thought in a person, act and feel doubtful to solve problems ${ }^{17}$ Independence in learning in elementary schools is an important role in which students can complete assignments, believe in their abilities, and not depend on others will affect their personality in the future. Cultivating independent character in students is very appropriate when children are

10 M Ali, Guru Dalam Proses Belajar Mengajar (Bandung: Sinar baru Algensindo, 2010); Thoifuri, Menjadi Guru Inisiator (Semarang: Media Campus, 2013).

${ }^{11}$ Arif Jati Atmaja, "Studi Minat Dan Hasil Belajar Antara Metode Klasikal Powerpoint Dengan Metode Berbantu Media Flash Pada Siswa Kelas VIII SMPN 2 Boja. Universitas Negeri Semarang” (PhD Thesis, Universitas Negeri Semarang, 2016); Ali, Guru Dalam Proses Belajar Mengajar; Novan Ardy Wiyani, Manajemen Pendidikan Karakter: Konsep Dan Implementasinya Di Sekolah, (Yogyakarta: Pedagogia, 2012).

${ }_{12}$ Monika Aprila Sari and Zafri Zafri, "Gambaran Minat Belajar Siswa Terhadap Variasi Gaya Mengajar Guru Pada Mata Pelajaran Sejarah Di SMA,” Jurnal Halaqah 1, no. 4 (2019): 460-68, https://doi.org/10.5281/zenodo.3524797.; Muhammad Safari, Riswan Jaenudin, and Dewi Koryati, “Analisa Gaya Mengajar Guru Ekonomi Di SMA Negeri Se-Kecamatan Lahat," Jurnal PROFIT Kajian Pendidikan Ekonomi Dan Ilmu Ekonomi 1, no. 2 (2014): 169-84, https://doi.org/10.36706/jp.v1i2.5607.

${ }^{13}$ Ali, Guru Dalam Proses Belajar Mengajar; Thoifuri, Menjadi Guru Inisiator.

${ }^{14}$ Ali, Guru Dalam Proses Belajar Mengajar.

15 Safari, Jaenudin, and Koryati, “Analisa Gaya Mengajar Guru Ekonomi Di Sma Negeri SeKecamatan Lahat."

16 Lev Semenovich Vygotsky, Mind In Society: The Development Of Higher Psychological Processes (Cambridge, MA: Harvard University Press, 1980).

17 D. Desmita, Psikologi Perkembangan Peserta Didik: Panduan Bagi Orang Tua Dan Guru Dalam Memahami Psikologi Anak Usia SD, SMP, Dan SMA (Bandung: Remaja Rosdakarya, 2011). 
elementary school age. Because at that age, the child is developing ${ }^{18} \mathrm{~A}$ form of independent character education that needs to be instilled in elementary school children, namely being able to analyze, solve problems, take responsibility, not give up easily, be confident, and use free time well. ${ }^{19}$

This research is in line with the research that has been conducted ${ }^{20}$ on teacher teaching styles, the results of the study show that the teaching style of teachers, learning discipline, and peers simultaneously influence learning achievement. In contrast, partially the teacher's teaching style, Learning discipline, and peers positively affect learning achievement. Teachers are expected to have a fun teaching style so that students do not feel bored or upset in the teaching and learning process. Then the independent character of a student in learning has a high relationship or influence on learning outcomes. ${ }^{21}$ So that independent learning will encourage someone to take an aspect of learning activities.

This statement is following the statement of Vygotsky, ${ }^{22}$ which states that the interaction between teachers and students according to the stages of student development. In addition to the interaction of teachers and students, understanding each other and providing opportunities for students to learn independently by utilizing information and communication technology ${ }^{23}$ is also an important component in the learning process. By understanding this, it is possible to have a style shift in teaching teachers and create students with a character of independence. ${ }^{24}$

18 Maryono Maryono, Hendra Budiono, and Resty Okha, "Implementasi Pendidikan Karakter Mandiri Di Sekolah Dasar," Jurnal Gentala Pendidikan Dasar 3, no. 1 (2018): 20-38, https://doi.org/10.22437/gentala.v3i1.6750.

${ }^{19}$ Budiyanto and Machali, "Pembentukan Karakter Mandiri Melalui Pendidikan Agriculture Di Pondok Pesantren Islamic Studies Center Aswaja Lintang Songo Piyungan Bantul Yogyakarta."

${ }^{20}$ Lathifah Al Khumaero and Sandy Arief, "Pengaruh Gaya Mengajar Guru, Disiplin Belajar, Dan Teman Sebaya Terhadap Prestasi Belajar,” Economic Education Analysis Journal 6, no. 3 (2017): 698710, https://journal.unnes.ac.id/sju/index.php/eeaj/article/view/20281.

${ }^{21}$ Fadillah Rahmayani, "Hubungan Karakter Mandiri Siswa Dalam Belajar Dengan Hasil Belajar Siswa," Jurnal Pendidikan Edutama 6, no. 2 (2019): 87-94, http://dx.doi.org/10.30734/jpe.v6i2.510.

${ }^{22}$ Vygotsky, Mind in Society. Schools."

${ }^{23}$ Bae, Les DeBusk-Lane, and Lester, "Engagement Profiles of Elementary Students in Urban

24 Joko Sulianto et al., “Analisis Implementasi Pembelajaran Di Sekolah Dasar Pada Pengembangan Model Advance Organizer Berbasis Pendekatan Open Ended Untuk Meningkatkan Penalaran Siswa," International Journal of Elementary Education 3, no. 4 (2019): 396-403, https://ejournal.undiksha.ac.id/index.php/IJEE/article/view/21312. 
Diah Fitrotul Auliana, Arief Rahman Hakim, Dyah Triwayuningtyas, Yulianti, Mohm Faiz Mohd Yaakob, Diana Wulandari

Based on the results of observations with students' independent character indicators $^{25}$ in the learning process in ES in the odd semester of 2019/2020, the teaching styles of teachers in elementary schools, namely grades IV, V, and VI as a whole, have many similarities, namely using classical teaching styles in teaching. However, some teachers use personalized and interactional technological teaching styles.

Some students are still unable to complete their assignments independently. Besides, students do not pay attention when the teacher is explaining the material and assignments to be done. When the discussion was taking place, the students did not pay attention to what task they had to do, still roaming around looking for answers even though groups had been formed. Based on these problems, the researcher will use an interactional teaching style because the interactional teaching style is considered appropriate for elementary school students' early stages of development. The interactional teaching style is a teaching style that is appropriate for the developmental stages of students at elementary school age. ${ }^{26}$ The age of elementary school children between 7-11 years is the concrete operational stage where children can begin to be invited to learn independently because children can think logically about concrete events, classify objects into different groups, understand the concept of conversation, organizing objects into hierarchical classes (classification) and placing objects in an orderly order (serialization). So the interaction teaching style can be used as an alternative in increasing students' independence at the elementary level because the independent nature is very important for students, given the tendency of students who are currently developing with dependency, laziness, and undisciplined characteristics ${ }^{27}$. After all, children at elementary school age have to fight for independence. The

25 Nova Fahradina, Bansu Irianto Ansari, and Saiman Saiman, "Peningkatan Kemampuan Komunikasi Matematis Dan Kemandirian Belajar Siswa SMP Dengan Menggunakan Model Investigasi Kelompok," Jurnal Didaktik Matematika 1, no. 2 (2014), http://www.erepository.unsyiah.ac.id/DM/article/view/2077.

${ }^{26}$ Saghir Ahmad et al., "Play and Cognitive Development: Formal Operational Perspective of Piaget's Theory.," Journal of Education and Practice 7, no. 28 (2016): 72-79, https://eric.ed.gov/?id=EJ1118552.; Safdar Rehman Ghazi and Karim Ullah, "Concrete Operational Stage Of Piaget's Cognitive Development Theory: An Implication In Learning General Science," Gomal University Journal of Research 31, no. 1 (2015): 78-89, http://www.gujr.com.pk/index.php/GUJR/article/view/326.; Dean Barker, Mikael Quennerstedt, and Claes Annerstedt, "Inter-Student Interactions And Student Learning In Health And Physical Education: A Post-Vygotskian Analysis," Physical Education and Sport Pedagogy 20, no. 4 (2015): 409-26, https://doi.org/10.1080/17408989.2013.868875.

27 Toni Nasution, "Membangun Kemandirian Siswa Melalui Pendidikan Karakter," Ijtimaiyah: Jurnal Pendidikan Dan Ilmu Sosial 2, no. 1 (2018), http://repository.uinsu.ac.id/id/eprint/10684. 
independent character that is in students will indirectly be reflected in everything they do. The problem of the character of the nation's children is also the responsibility of the school as well as the teachers in the school. ${ }^{28}$ The purpose of this study was to determine the effect of interactional teaching styles on the independent character of elementary school students

\section{RESEARCH METHODS}

The approach in this study uses quantitative research, which is a technique or method that emphasizes a subject that is observed in large numbers using numbers of statistical work, design, and controlled experiments. ${ }^{29}$ Using quantitative research is because the researcher intends to eliminate subjectivity or angles in the study to obtain valid data. This type of research is causal associative because it analyzes the relationship between one variable and another.

The total population in this study was 170 high-grade elementary school students at SDN Ketapanrame 1 Trawas, namely class IV A, IV B, VA, VB, VI A, and VI B in the even semester of 2019/2020. The error rate taken by the researcher was $5 \%$, so the sample size was 113 (in the formula table from Issac and Michael). By using a simple random sampling technique or taking randomly. The method of data accumulation used in this study was a questionnaire and documentation. The statistical description used is validity test, reliability test, normality test, simple linear regression test. Meanwhile, data analysis using a simple linear regression test is seen from the t-test.

\section{RESULT AND DISCUSSION}

This study used a simple regression model because only one independent variable was analyzed. This study used two variables, namely the teacher's teaching style and the students' independent character. Based on data processing using SPSS version 22.00 for windows. The validity test results of the teacher's teaching style are all valid because the significance value is more than 0.05 . While the results of the reliability of the teacher's

${ }^{28}$ Yusutria Yusutria and Rina Febriana, "Aktualisasi Nilai-Nilai Kemandirian Dalam Membentuk Karakter Mandiri Siswa," Ta'dib: Jurnal Pendidikan Islam 8, no. 1 (May 1, 2019): 577-82, https://doi.org/10.29313/tjpi.v8i1.4575.

29 Zainal Arifin, Penelitian Pendidikan Metode Dan Paradigma Baru (Bandung: PT Remaja Rosdakarya, 2012); Sugiyono, Metode Penelitian Kuantitatif, Kualitatif, Dan R\&D (Bandung: Alfabeta, 2018). 
Diah Fitrotul Auliana, Arief Rahman Hakim, Dyah Triwayuningtyas, Yulianti,

Mohm Faiz Mohd Yaakob, Diana Wulandari

teaching style are declared reliable because the value Cornbach's alphais close to 1.The following are the results of the prerequisite test for class $5 \mathrm{~b}$ of the interactional teacher's teaching style:

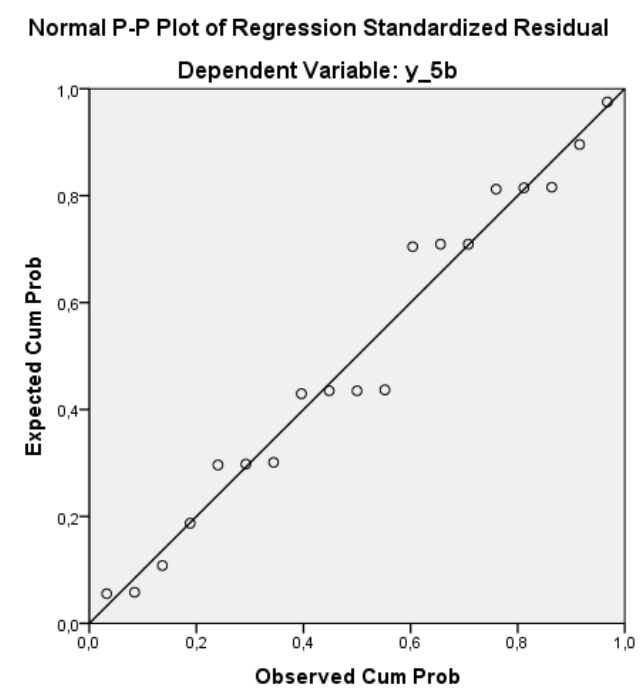

Figure 1

Normality Test for Class $5 \mathrm{~B}$, the teaching style of the interactional teacher.

Based on Figure 1, the normality test for Class $5 \mathrm{~B}$, the teaching style of the interactional teacher, it can be concluded that the distribution of residual points is around the normal line. This happens because the residual points come from data with a normal distribution. This indicates that the regression has met the requirements for normality.

Table 1

ANOVA Table

\begin{tabular}{|c|c|c|c|c|c|c|c|}
\hline & & & $\begin{array}{l}\text { Sum of } \\
\text { Squares }\end{array}$ & df & $\begin{array}{l}\text { Mean } \\
\text { Square }\end{array}$ & $\mathrm{F}$ & Sig. \\
\hline \multirow{5}{*}{$\begin{array}{l}\mathrm{y} \_5 \mathrm{~b} * \\
\mathrm{x} \_5 \mathrm{~b}\end{array}$} & \multirow{3}{*}{$\begin{array}{l}\text { Between } \\
\text { Groups }\end{array}$} & (Combined) & 74.325 & 9 & 8.258 & 4.415 & .019 \\
\hline & & Linearity & 57.476 & 1 & 57.476 & 30.730 & .000 \\
\hline & & $\begin{array}{l}\text { Deviation from } \\
\text { Linearity }\end{array}$ & 16.848 & 8 & 2.106 & 1.126 & .428 \\
\hline & \multicolumn{2}{|c|}{ Within Groups } & 16.833 & 9 & 1.870 & & \\
\hline & \multicolumn{2}{|l|}{ Total } & 91.158 & 18 & & & \\
\hline
\end{tabular}

Source: data processed by researchers (2020) 
From table 1 . The results of the linearity test for Class $5 \mathrm{~B}$ of the interactional teacher's teaching style above can be obtained from the results of Deviation from linearity of 428 . Because the significance value is $>0.05$, it is concluded that there is a linear relationship between the interactional teacher's chasing style and the students' independent character. And to determine the effect of a significant independent variable teaching style teacher with a dependent variable, independent character of students is using the t-test research results can be seen in the table below:

Table 2

Test Results t Teachers Teaching Style Character Against Independent Student

\begin{tabular}{|c|c|c|c|}
\hline \multicolumn{4}{|c|}{$\begin{array}{c}\text { 4A Class } \\
\text { (Classical Teacher Teaching Style) }\end{array}$} \\
\hline Variabel & t-count & Sig & Information \\
\hline Constant & 4.184 & .001 & \\
\hline Character & .461 & .651 & No effect \\
\hline \multicolumn{4}{|c|}{$\begin{array}{c}\text { 4B Class } \\
\text { (Technological Teacher Teaching Style) }\end{array}$} \\
\hline Constant & -1.268 & .222 & \\
\hline Character & 6.733 & .000 & Take effect \\
\hline \multicolumn{4}{|c|}{$\begin{array}{c}\text { 5A Class } \\
\text { (Teaching Style Teacher Personalization) }\end{array}$} \\
\hline Constant & 3.806 & .001 & \\
\hline Character & 5.106 & .000 & Take effect \\
\hline \multicolumn{4}{|c|}{$\begin{array}{c}\text { 5B Class } \\
\text { ( Interactional Teacher Teaching Style ) }\end{array}$} \\
\hline Constant & 6.821 & .000 & \\
\hline Character & 5.386 & .000 & Take effect \\
\hline
\end{tabular}

6A Class

(Classical Teacher Teaching Style)

\begin{tabular}{lcrr}
\hline Constant & 2.888 & .011 & \\
\hline Character & -780 & .447 & No effect \\
\hline & $6 B$ & Class
\end{tabular}

(Technological Teacher Teaching Style)

\begin{tabular}{llll}
\hline Constant & 2.135 & .049 & \\
\hline Character & 3.845 & .001 & Take effect \\
\hline
\end{tabular}

Source: processed research results (2020) 
Diah Fitrotul Auliana, Arief Rahman Hakim, Dyah Triwayuningtyas, Yulianti,

Mohm Faiz Mohd Yaakob, Diana Wulandari

To test the effect of learning method variables on students' independent character is as follows:

Based on table 01 above, the results of the t-test (partial significant-test) class 4 A classical teacher teaching style above the t-count value for variable $\mathrm{X}$ (classical teacher teaching style) of .461 with a significant level of .651. Because the significance level is greater than .05 , the $X$ variable (classical teacher teaching style) does not affect the $\mathrm{Y}$ variable (students' independent character).

Based on table 01 above, the results of the t-test (partial significant-test) for class $4 \mathrm{~B}$, the teaching style of technological teachers is above the t-count value for variable $\mathrm{X}$ (teaching style of technological teachers) of 6.733 with a significant level of .000 . Because the level of significance is less than .05 , so variable $\mathrm{X}$ (teaching style of technological teachers) affects variable $\mathrm{Y}$ (student's independent character).

Based on table 01 above the results of the t-test (partial significant-test) of class $5 \mathrm{~A}$ for the personalization teacher's teaching style, the result is that the tcount value for variable $X$ (personalization teacher teaching style) is 5.106 with a significant level of .000 . Because the significance level is less than .05 , so the variable $\mathrm{X}$ (personalization teacher teaching style) affects the $\mathrm{Y}$ variable (student's independent character).

Based on table 01 above, the results of the t-test (partial significant-test) in class $5 \mathrm{~B}$, the teaching style of the interactional teacher is above the value $(\mathrm{t}-$ count for the variable) $\mathrm{X}$ (teaching style of the interactional teacher) of 5.386 with a significant level of .000 Due (the significance level is smaller of .05, then the variable) $\mathrm{X}$ (interactional teacher teaching style) affects the variable $\mathrm{Y}$ (student's independent character).

Based on table 01 above, the results of the t-test (partial significant-test) for class 6 A classical teacher teaching style above the t-value for variable $\mathrm{X}$ (classical teacher teaching style) of -780 with a significant level of .447 Because the significance level is greater than .05, the variable $\mathrm{X}$ (classical teacher teaching style) does not affect the variable $\mathrm{Y}$ (student's independent character).

Based on table 01 above, the results of the t-test (partial significance test) of class $6 \mathrm{~B}$ above the t-value for variable $\mathrm{X}$ (teaching style of technological teachers) amounted to 3.845 with a significant level of .001 . Because the significance level is less than ..05, the variable $X$ (teaching style of the technological teacher) affects variable Y (student's independent character).

Judging from the results of the t-test data description, it is said that there is a significant influence between the interactional teaching style and the students' independent character. With indicators that teachers and students both have their respective roles, a study in groups always invites to interact with students and relate them to the actual situation. Based on table $01 \mathrm{t}$-test (partial significant-test) class $5 \mathrm{~B}$, the teaching style of interactional teachers is above the t-count value for variable $\mathrm{X}$ 
(teaching style of interactional teachers) of 5.386 significant level of .000 . Because the significance level is less than .05 , the variable $\mathrm{X}$ (the interactional teacher's teaching style) affects the Y variable (students' independent character) so that there is a partially significant influence between the teaching style of the interactional teacher and the character of the students.

The roles of teachers and students in this interactional teaching style are equally influential. ${ }^{30}$ Students here as social beings certainly interact with other people with various problems that must be faced individually. The teacher can design a situation in the classroom where it bonds with each other and can lead to a conversation between students. ${ }^{31}$ This teaching style, usually in the context of learning, focuses on events related to society's social and cultural aspects, especially the current characteristics. ${ }^{32}$

\section{CONCLUSION}

From the research data analysis, it can be concluded that this interactional teaching style is suitable for elementary school students because teaching elementary students needs a good approach and interaction between teachers and students. And to get perfect suggestions for further researchers, we recommend examining the influence of teaching styles for tall students regarding personalized teaching styles and technological teaching styles as appropriate for higher-level students such as junior high and high school students.

\section{REFERENCES}

Ahmad, Saghir, Abid Hussain Ch, Ayesha Batool, Khadija Sittar, and Misbah Malik. "Play and Cognitive Development: Formal Operational Perspective of Piaget's Theory." Journal of Education and Practice 7, no. 28 (2016): 72-79. https://eric.ed.gov/?id=EJ1118552.

Al Khumaero, Lathifah, and Sandy Arief. "Pengaruh Gaya Mengajar Guru, Disiplin Belajar, Dan Teman Sebaya Terhadap Prestasi Belajar." Economic Education Analysis Journal 6, no. 3 (2017): 698-710. https://journal.unnes.ac.id/sju/index.php/eeaj/article/view/20281.

30 Yu-Hsiu Liao et al., "An Exploration Of The Relationships Between Elementary School Teachers' Humor Styles And Their Emotional Labor," Teaching and Teacher Education 87 (2020): 102950, https://doi.org/10.1016/j.tate.2019.102950.

${ }^{31}$ Ali, Guru Dalam Proses Belajar Mengajar.

32 Safari, Jaenudin, and Koryati, “Analisa Gaya Mengajar Guru Ekonomi Di Sma Negeri SeKecamatan Lahat." 
Diah Fitrotul Auliana, Arief Rahman Hakim, Dyah Triwayuningtyas, Yulianti,

Mohm Faiz Mohd Yaakob, Diana Wulandari

Ali, M. Guru Dalam Proses Belajar Mengajar. Bandung: Sinar Baru Algensindo, 2010.

Arifin, Zainal. Penelitian Pendidikan Metode Dan Paradigma Baru. Bandung: PT Remaja Rosdakarya, 2012.

Atmaja, Arif Jati. "Studi Minat Dan Hasil Belajar Antara Metode Klasikal Powerpoint Dengan Metode Berbantu Media Flash Pada Siswa Kelas VIII SMPN 2 Boja. Universitas Negeri Semarang." PhD Thesis, Universitas Negeri Semarang, 2016.

Bae, Christine L, Morgan Les DeBusk-Lane, and Ashlee M Lester. "Engagement Profiles Of Elementary Students In Urban Schools." Contemporary Educational Psychology 62 (2020): 101880. https://doi.org/10.1016/j.cedpsych.2020.101880.

Barker, Dean, Mikael Quennerstedt, and Claes Annerstedt. "Inter-Student Interactions And Student Learning In Health And Physical Education: A Post-Vygotskian Analysis." Physical Education and Sport Pedagogy 20, no. 4 (2015): 409-26. https://doi.org/10.1080/17408989.2013.868875.

Brandmiller, Cornelius, Hanna Dumont, and Michael Becker. "Teacher Perceptions Of Learning Motivation And Classroom Behavior: The Role Of Student Characteristics." Contemporary Educational Psychology 63 (2020): 101893. https://doi.org/10.1016/j.cedpsych.2020.101893.

Budiyanto, Mangun, and Imam Machali. "Pembentukan Karakter Mandiri Melalui Pendidikan Agriculture Di Pondok Pesantren Islamic Studies Center Aswaja Lintang Songo Piyungan Bantul Yogyakarta.” Jurnal Pendidikan Karakter, no. 2 (2014). https://doi.org/10.21831/jpk.v0i2.2784.

Desmita, D. Psikologi Perkembangan Peserta Didik: Panduan Bagi Orang Tua Dan Guru Dalam Memahami Psikologi Anak Usia SD, SMP, Dan SMA. Bandung: Remaja Rosdakarya, 2011.

Dilekli, Yalçın, and Erdoğan Tezci. "The Relationship Among Teachers' Classroom Practices For Teaching Thinking Skills, Teachers' Self-Efficacy Towards Teaching Thinking Skills And Teachers' Teaching Styles." Thinking Skills and Creativity 21 (2016): 144-51. https://doi.org/10.1016/j.tsc.2016.06.001.

Fahmy, Rahmi, Nasri Bachtiar, Rida Rahim, and Melini Malik. "Measuring Student Perceptions To Personal Characters Building In Education: An Indonesian Case In Implementing New Curriculum In High School." Procedia-Social and Behavioral $\quad$ Sciences $211 \quad$ (2015): https://doi.org/10.1016/j.sbspro.2015.11.112.

Fahradina, Nova, Bansu Irianto Ansari, and Saiman Saiman. "Peningkatan Kemampuan Komunikasi Matematis Dan Kemandirian Belajar Siswa SMP Dengan Menggunakan Model Investigasi Kelompok.” Jurnal Didaktik Matematika 1, no. 2 (2014). http://www.e-repository.unsyiah.ac.id/DM/article/view/2077.

Ghazi, Safdar Rehman, and Karim Ullah. "Concrete Operational Stage Of Piaget's Cognitive Development Theory: An Implication In Learning General Science." Gomal University Journal of Research 31, no. 1 (2015): 78-89. http://www.gujr.com.pk/index.php/GUJR/article/view/326.

Liao, Yu-Hsiu, Si-Yu Luo, Meng-Hua Tsai, and Hsueh-Chih Chen. "An Exploration Of The Relationships Between Elementary School Teachers' Humor Styles And 
Their Emotional Labor.” Teaching and Teacher Education 87 (2020): 102950. https://doi.org/10.1016/j.tate.2019.102950.

Maryani, Ika, and Sri Tutur Martaningsih. "Primary School Teachers' Perception About Curriculum 2013 Assessment System." Scholaria: Jurnal Pendidikan Dan Kebudayaan 7, no. 2 (2017): https://doi.org/10.24246/j.scholaria.2017.v7.i2.p153-164.

Maryono, Maryono, Hendra Budiono, and Resty Okha. "Implementasi Pendidikan Karakter Mandiri Di Sekolah Dasar." Jurnal Gentala Pendidikan Dasar 3, no. 1 (2018): 20-38. https://doi.org/10.22437/gentala.v3i1.6750.

Ministry of Education and Culture. Kajian Dan Pedoman Penguatan Pendidikan Karakter (PPK). Jakarta: MoEC, 2016.

Nasution, Toni. "Membangun Kemandirian Siswa Melalui Pendidikan Karakter." Ijtimaiyah: Jurnal Pendidikan Dan Ilmu Sosial 2, no. 1 (2018). http://repository.uinsu.ac.id/id/eprint/10684.

Nurhamidah, Ilin. "Problematika Kompetensi Pedagogi Guru Terhadap Karakteristik Peserta Didik." Jurnal Teori Dan Praksis Pembelajaran IPS, 2018, 27-38. http://dx.doi.org/10.17977/um022v3i12018p027.

Rahmayani, Fadillah. "Hubungan Karakter Mandiri Siswa Dalam Belajar Dengan Hasil Belajar Siswa." Jurnal Pendidikan Edutama 6, no. 2 (2019): 87-94. http://dx.doi.org/10.30734/jpe.v6i2.510.

Rusman, Rusman. "Implementasi Kurikulum 2013 Di Sekolah Dasar Studi Tentang Best Practice Yang Dilakukan Guru Sekolah Dasar Dalam Perencanaan, Pelaksanaan, Dan Penilaian Kurikulum 2013." Al-Bidayah: Jurnal Pendidikan Dasar Islam 10, no. 2 (2018): 135-50. https://doi.org/10.14421/albidayah.v10i2.166.

Safari, Muhammad, Riswan Jaenudin, and Dewi Koryati. "Analisa Gaya Mengajar Guru Ekonomi Di SMA Negeri Se-Kecamatan Lahat." Jurnal PROFIT Kajian Pendidikan Ekonomi Dan Ilmu Ekonomi 1, no. 2 (2014): 169-84. https://doi.org/10.36706/jp.v1i2.5607.

Sari, Monika Aprila, and Zafri Zafri. "Gambaran Minat Belajar Siswa Terhadap Variasi Gaya Mengajar Guru Pada Mata Pelajaran Sejarah Di SMA." Jurnal Halaqah 1, no. 4 (2019): 460-68. https://doi.org/10.5281/zenodo.3524797.

Sugiyono. Metode Penelitian Kuantitatif, Kualitatif Dan R\&D. Bandung: Alfabeta, 2018.

Sulianto, Joko, Sunardi Sunardi, Sri Anitah, and Gunarhadi Gunarhadi. "Analisis Implementasi Pembelajaran Di Sekolah Dasar Pada Pengembangan Model Advance Organizer Berbasis Pendekatan Open Ended Untuk Meningkatkan Penalaran Siswa." International Journal of Elementary Education 3, no. 4 (2019):

396-403. https://ejournal.undiksha.ac.id/index.php/IJEE/article/view/21312.

Thoifuri. Menjadi Guru Inisiator. Semarang: Media Campus, 2013.

Vygotsky, Lev Semenovich. Mind In Society: The Development Of Higher Psychological Processes. Cambridge, MA: Harvard University Press, 1980. 
Diah Fitrotul Auliana, Arief Rahman Hakim, Dyah Triwayuningtyas, Yulianti,

Mohm Faiz Mohd Yaakob, Diana Wulandari

Widodo, Hendro. "Penguatan Pendidikan Karakter Di SD Muhammadiyah Macanan Sleman Yogyakarta." Lentera Pendidikan: Jurnal Ilmu Tarbiyah Dan Keguruan 22, no. 1 (2019): 40-51. https://doi.org/10.24252/lp.2019v22n1i4.

Wiyani, Novan Ardy. Manajemen Pendidikan Karakter: Konsep Dan Implementasinya Di Sekolah. Yogyakarta: Pedagogia, 2012.

Yusutria, Yusutria, and Rina Febriana. "Aktualisasi Nilai-Nilai Kemandirian Dalam Membentuk Karakter Mandiri Siswa." Ta'dib : Jurnal Pendidikan Islam 8, no. 1 (May 1, 2019): 577-82. https://doi.org/10.29313/tjpi.v8i1.4575.

Zainuddin, HM. "Implementasi Kurikulum 2013 Dalam Membentuk Karakter Anak Bangsa." Universum: Jurnal KeIslaman Dan Kebudayaan 9, no. 1 (2015). https://doi.org/10.30762/universum.v9i1.80. 
The Influence of Interactional...

This page is intentionally left blank 